\title{
The Business Process Re-Engineering Strategy: It's Impact on the Performance of Companies Manufacturing Food in Kenya
}

\author{
Richard Nyaanga Ongeri, Peterson Obara Magutu, Kate Litondo
}

\begin{abstract}
The main objective of the study was to determine the relationship between BPR strategy and performance of food manufacturing companies in Kenya. The population of the study comprised of the food manufacturing companies in Kenya. A descriptive cross-sectional survey design was adopted in data collection and analysis. Primary data was collected from respondents using structured questionnaire, while secondary data was collected from published firm's financial reports. Out of the 75 respondents targeted by the study, 44 respondents forming $56.67 \%$ response rate, which was considered adequate for analysis. $63.9 \%$ of variations in the overall firm performance is explained by variations in the BPR strategy namely resources mobilization for BPR, sponsorship and commitment, BPR cross functional teams, analytical processes selection, BPR prototypes, management of re-engineered processes, clear BPR definition and vision. Thus, there is a significant relationship between BPR strategy and performance of food manufacturing companies in Kenya. This research makes several noteworthy contributions to the existing theory. Conceptually, the empirical relationship between BPR strategy and firm performance is significant where BPR strategy constructs independently and positively plays a role of fostering firm performance whereby the three significant predictors were: BPR prototypes, clear BPR definition \& vision, and analytical processes selection. These three are distinct development elements of the BPR strategy which competitors are unable to imitate in the food manufacturing. The findings of this study offer suggestions that are beneficial to policy makers in the food-manufacturing sector in Kenya. Kenyan manufacturing firms have previously lacked fits well into the existing body of knowledge by holding that BPR strategy influence the firm's level of performance and vice versa.
\end{abstract}

Index Terms - BPR strategy, Performance, Food Manufacturing Companies and Kenya.

\section{INTRODUCTION}

In today's global competition and ever changing marketing place, firms are pushed to rethink their business processes to adopt and succeed in their operating environment. Business success is also informed by the potential benefits of emerging technologies, which can catalyze the implementation of fundamental, and radical changes in an organization order to thrive and operate successfully, it is inevitable for organizations to adjust to changes in their environment. The challenge for organizations is on how to find better ways, methods, and strategies that will decrease the operational cost while increasing productivity for improved service delivery.

Published on October 30, 2020.

Richard Nyaanga Ongeri, Department of Management Science, University of Nairobi, Nairobi, Kenya.

(corresponding e-mail: nyaangarichardo@gmail.com)

Peterson Obara Magutu, Department of Management Science, University of Nairobi, Nairobi, Kenya.

(e-mail: magutumop@ gmail.com)
These methodologies and strategies can range from incremental approaches, change management and cost containment. The incremental approaches, inter-global competitive market are no longer effective hence the need for radical and break through techniques especially the reengineering their business processes [1]-[3].

The key benefits of implementing breakthrough initiatives and projects are to transform radically the firm's operations to achieve improvement in cost containment, improve on quality, which will eventually improve service delivery. Subsequently the design of business processes will lead to error prevention process upgrade and employee participation in joint problem solving. The common pervasive tools used to transform and achieve competitive include Business process redesign and most organizations around the business world are employing business process re-engineering as the most instrumental strategy to drum up growth in profits, enhance service delivery, realize good performance and attain competitiveness [4], [5].

Strategy in its wider context is a mixture of knowledge and assumptions about the organization, its goals, objectives, action, milestones, budgets and plans that are based on the knowledge of customer, suppliers, the general environment, actions of the competitors and a number of other organizational factors. Re-engineered organizations attempt to achieve this responsiveness through self-managed teams conducting the actual work that delivers value to the customer [6]. Business process re-engineering (BPR) is "the fundamental rethinking and radical redesign of business processes to achieve dramatic improvements in critical measures of performance such as cost, quality, service, job satisfaction, and speed" [7]. [8] citing [9] BPR is a major management approach that can focus on doing things in a better way that is clearer and easier to achieve a radical improvement on quality, speed, customer service, and reduction in cost. Among the latest management 'buzzwords' presented to organizations to make them competitive, business process re-engineering is considered very instrumental.

Organizational performance reflects an organization's understanding and knowledge regarding customer needs and expectations [10]. [11] found that performance could be improved through good leadership practice and provision of customized service design for select clientele in the service sector. Hence, business organization can maximize their

Kate Litondo, Department of Management Science, University of Nairobi, Nairobi, Kenya.

(e-mail: klitondo@uonbi.ac.ke) 
customer satisfaction for better profitability, increased sales volume, which ultimately improves overall performance benefit [12].

In an increasingly competitive landscape, food companies involved in new product development and manufacture are facing more and more challenges. The manufacturing industry as a whole is preparing for a tough year. According to a survey carried out shows that less than a quarter $(23 \%)$ of those manufacturing firms surveyed expected opportunities to outnumber risks in 2017. For food manufacturers there is a lot to contend with a global demand on resources, an increasing number of competitors, economic uncertainty and many more. Consumers want healthier products but without any compromise on taste. As a result, they are studying product labels more than ever before, wanting to know exactly what is in the food they are consuming. This means that food manufacturers need to develop products with reduced (or no) salt, sugar, trans and saturated fats, and without compromising on flavor [13].

\section{RESEARCH PROBLEM}

The following research gap shall be addressed by the study, most BPR studies have focused on social aspects of change management rather than the schematic effect of BPR strategy on firm performance based on sound theoretical foundations and models [14], hence need to test the effect of BPR strategy and Firm performance. Maintaining the best possible methods of storing, packaging, preserving, and distributing products remains a constant challenge hence the need to reengineer and improvement of the IT infrastructure [13], [15]. However, despite the much research, the moderating role of BPR on service delivery which should be customeroriented and process-focused has only been scantly investigated empirically and to a very small extent.

Consequently, the current study sort to determine the relationship between BPR strategy and performance of food processing companies in Kenya. It will be therefore guided by the following research questions: Does business process re-engineering strategy affect the performance of companies manufacturing food in Kenya?

\section{RESEARCH OBJECTIVES}

The specific research objective, which the study sought to achieve was to determine the effect of BPR strategy on performance of food manufacturing companies in Kenya.

\section{LITERATURE REVIEW}

The intent of the literature review is to identify and discuss a theoretical framework that can be used as the basis of highlighting the impact of BPR strategy and firm performance. There is need therefore to try and understand the underlying themes of BPR Strategy and firm performance and their multi-dimensions as in this section.

$\mathrm{RBV}$ is the underlying theory to explain the impact of organizational resources on sustaining a competitive advantage for superior firm performance compared to their competitors [16], [17]. RBV in BPR strategy implementation requires the firm to develop and deploy strategic resources (assets and capabilities) for the realization of superior competitive advantage. These strategic resources should be identified, categorized and prioritized in pursuant of enhanced competitive edge [18].

Firms need to focus on resource competence as opposed to product market in the global turbulent business environment [19]. RBV theory provides a better understanding on the interaction between BPR strategy and performance of companies manufacturing food in Kenya

Performance in an organizational is a reflection on the firm's knowledge which informs the understanding of customer needs and expectations [20]. Through good leadership practice and provision of customized service design in the service sector could lead to improved overall firm performance as evidenced by maximized customer satisfaction for better profitability and increased sales volume, which ultimately improves overall performance benefit [11].

Generally, organizational performance is measured using financial or both financial and non-financial indicators. There are number of studies in the literature that use non-financial measures to evaluate the effectiveness and performance of organization. It is suggested that four models i.e. human relations; internal process; open system and rationale goal model could represent the organizational performance [21], [22]. Appropriate performance measures depend on the organizations and their objectives i.e. profitability, market share and cost reduction. Organizational Development and Performance takes a look at the firm's level of efficiency and way to improve its current activity level in order to meet up to standards and Succeed the competitive pressure. Organizational performance could be linked with market orientation, organization learning, human resource productivity, quality improvement or any other component [23].

Organizations have been measuring performance using outdated costing systems and financial reporting that do not reflect the need for customer satisfaction. To mesh the two concepts together (BPR and Firm Performance) and for Firm Performance to play its role in the change process, a different approach to measure in the achievement of customer-focused, result-oriented operations is required. This means that the Firm Performance has to balance a number of dimensions and to play a number of roles to enable BPR to succeed. A relevant and congruent performance measurement system is a prerequisite for the successful design and implementation of BPR. These two conflicting concepts call for a conceptual model through a study to reconcile them [6], [24].

Proposition I: The implementation of a sound business process re-engineering strategy improves firm performance.

The intended study proposes that BPR strategy can be associated with improved firm performance. The literature review has presented the empirical studies to enable us to understand the relationship between BPR strategy and firm performance. This has been informed by the gaps in literature and the intended study will addressed them as indicated in Table1. 
TABLE 1: SUMMARY OF KNOWLEDGE GAPS ON BUSINESS PROCESS REENGINEERING AND FIRM PERFORMANCE

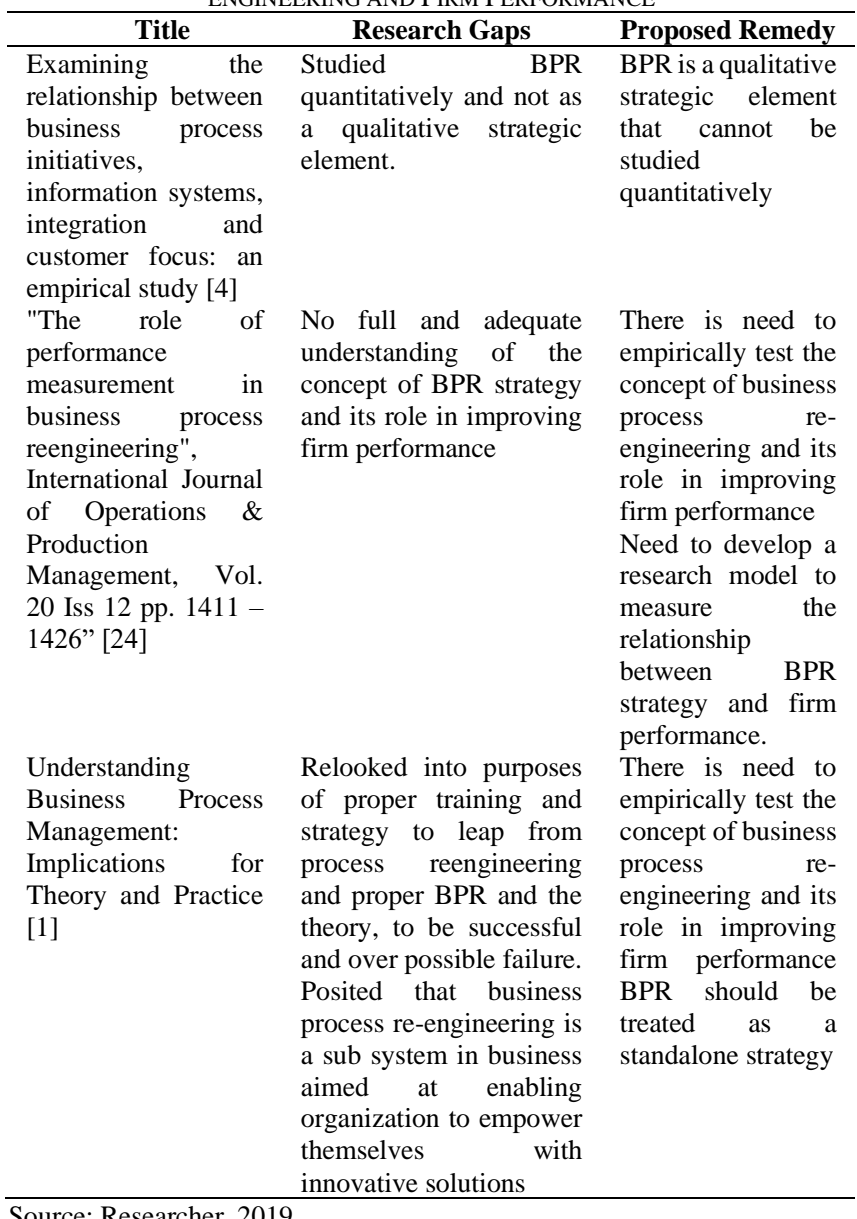

Source: Researcher, 2019.

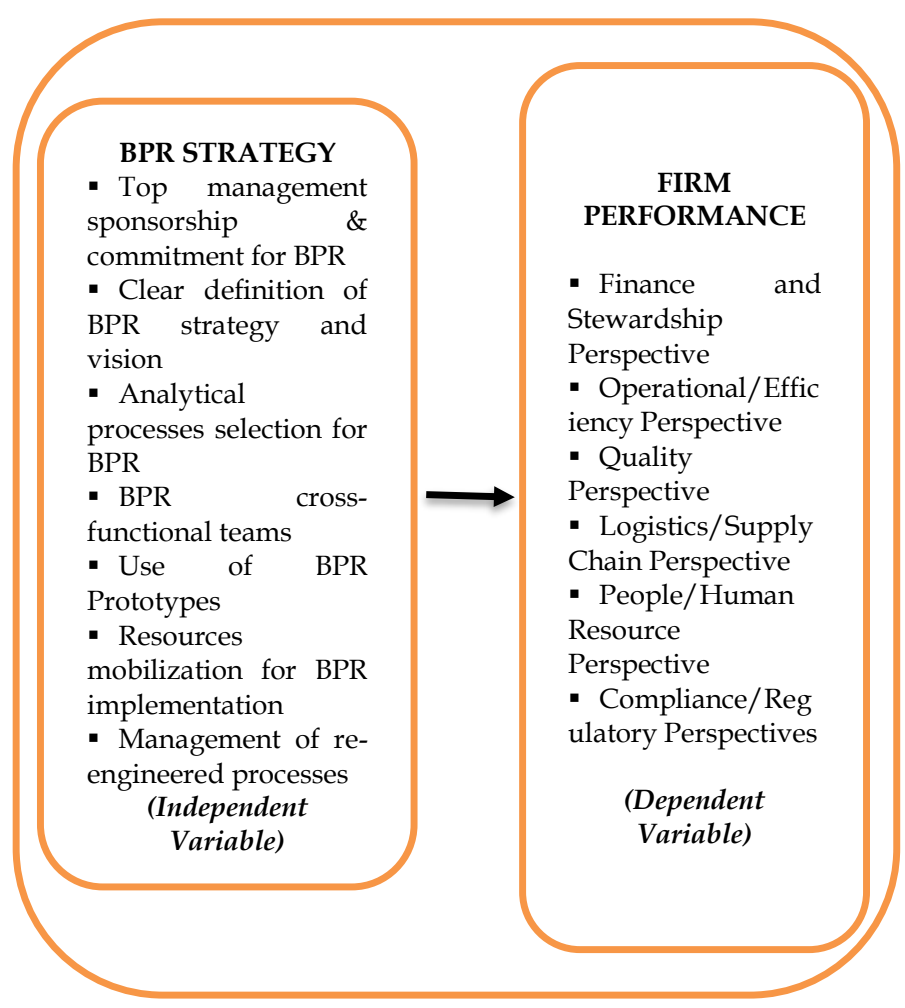

Fig. 1. Conceptual Model.

Source: Researcher, 2019. process reengineering strategy and firm performance. The iterative and interactive model is built on the relationship that may be implicit and or/ explicit in the body of literature reviewed and is structured so as to enable addressing the research gap. The conceptual model developed aids the study of the direct effect of BPR strategy on firm performance.

The preceding discussion suggests that the business process reengineering strategy and firm performance can be examined. The links between business process reengineering strategy and firm performance are examined through this framework as hypothesized by testing whether:

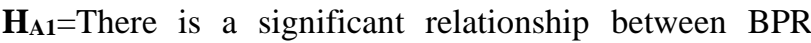
strategy and performance of food manufacturing companies in Kenya.

\section{RESEARCH METHODOLOGY}

This section is set to highlight and discuss the methodology proposed for the study in question. The methodological sections proposed are; philosophy of the research, the design that will be employed, population to be targeted highlighting also the methods for data collection, measurements of validity and reliability and also a section of how variables pertaining the study will be operationalized and finally analytical techniques to be employed and the pre-analysis of the regression assumptions.

This study adopted the positivist approach based on the argument that the study sets to empirically and objectively analyze the relationships existing among the variables in question and also the hypothesis were drawn from the theories. The positivist orientation will also enable hypotheses testing, acceptance or rejected based on the tested results thus leading to further research. Positivism seeks to unveil the fact or causes of social phenomena. Positivism approach is theory testing as opposed to epistemology which is theory building.

The study will adopt a descriptive cross-sectional design. Information about the subjects gathered represents a snapshot of what is going on at that point in time. In view of the breath of the study, cross-sectional survey affords the researcher the opportunity to capture data on business process reengineering strategy, information technology infrastructure, service delivery and their individual \& joint influence on performance of food manufacturing companies in Kenya. The unit of analysis and population of the study will be seventyfive (75) food manufacturing companies in Kenya. These food manufacturing companies are classified into companies Offering: Cereals manufacturing, Food Manufacturing Consultancy, Food Flavours Manufacturing, Food Hygiene, Food Packaging, Food Preparation, Food Processing and Sugarcraft Supplies.

The target respondents will be the chief executive officer (CEOs) and with their permission, the production or operations managers depending on the structure of the particular company. The respondents will be picked to represent all the stratas of 75 food manufacturing firms as indicated in Table 2.

The conceptual framework presented in figure 1 below captures the relationship between organizational business 
TABLE 2: SAMPLE SIZE DETERMINATION

\begin{tabular}{|c|c|}
\hline Food Manufacturing Firms Cluster & $\begin{array}{l}\text { Population } \\
\text { (P) }\end{array}$ \\
\hline Companies Offering Cereals manufacturing & 10 \\
\hline $\begin{array}{l}\text { Companies } \\
\text { Consultancy }\end{array}$ Offering Food Manufacturing & 3 \\
\hline Companies Offering Food Flavours Manufacturing & 7 \\
\hline Companies Offering Food Hygiene & 2 \\
\hline Companies Offering Food Packaging & 14 \\
\hline Companies Offering Food Preparation & 2 \\
\hline Companies Offering Food Processing & 19 \\
\hline Companies Offering Sugarcraft Supplies & 18 \\
\hline Total & 75 \\
\hline
\end{tabular}

Primary data was collected through a methodological triangulation method utilizing a questionnaire survey method. Structured questionnaire comprised of closed and open-ended questions developed in line with the objectives and hypothesis of the study and guided by the literature reviewed as well as theories upon which the study is anchored on. This approach was used by [25] who applauded it because of its ability to maximize the benefit of standard and descriptive data that the interviews generate. The study will rely on both primary and secondary data sources because they reinforce each other [26].

Reliability can be well defined according to [25] as the measurement of the extent an instrument under the research is yielding the results after trials have been done repeatedly. This is measured or rather estimated by use of a ratio called Cronbach's alpha which have the capability in assessing the correlation average of items in a test or the internal consistency measure.

The coefficient values of the Cronbach's alpha that is in the range of 0 and 1 is interpreted that when it's very high, then it means the items on the instrument correlate very highly within themselves thus existence of the consistency in measuring the intended concepts [27]. As far as [28] is concerned 0.7 coefficient value is considered better and strong and thus this particular study will apply the 0.7 cut off point. Validity is the degree upon which the processed information is the true representation of the phenomenon of the study. It represents the argument that an instrument should yield results precisely to measure the intended objective by enabling the researcher to hit a bulls' eye of the objective in the interest of the population of the study in general [27]. Both construct validity and content validity will be used in adapting the measures for the variables in this study. The questionnaire was pre-tested to ascertain its relevance. Content validity will be done by testing and retesting the questionnaire that will cover all the four main areas of the study.

The study tested for the assumption of linear relationship between the dependent and independent variables using scatter plots which requires an assumption of linearity of data, that is, the data will be sampled from a population that relates to the independent and dependent variable in a linear form. [25] pointed out that the chance of non-linear relationships is high in the social sciences, thus it's essential to test for linearity. Normality test will be conducted to ensure that normality assumptions are not violated at analysis stage. Normality of data will be established using graphical or numerical method. According to [27] neither the numerical nor graphics individually provide conclusive evidence of normality. Therefore, the study will establish normality of the data for each independent variable both numerically and graphically. Descriptive statistics will be performed to derive the means, median, standard deviations, skewness and kurtosis for describing normality of the data. [27] observes that a normally distributed variable should have skewness and kurtosis near zero with mean closer to median.

Multi-collinearity is the unacceptable high level of correlation among the independent variables making it hard to separate the effects of the individual independent variables. The test for multi-collinearity will be performed using Condition Index (CI), Variance Inflation Factors (VIF) and tolerance. [25], [27] observes that multi-collinearity has small values for tolerance and large VIF values. The acceptable range of $\mathrm{CI}<30, \mathrm{VIF}<5$, and tolerance $>0.2$ will be applied to test multi-collinearity. The study will test for homoscedasticity by use of Levene's test of homogeneity of variance at the level of significance of $p<0.05$. The violation of homoscedasticity (heteroscedasticity) is present when the size of the error term differs across values of an independent variable. Low heteroscedasticity has little effect on significance tests, but high heteroscedasticity weakens/distorts the analysis thus increasing possibility of committing type I error [27].

For this study, both descriptive and inferential statistic (mean scores, standard deviations, percentages, and frequency distribution) will be used. These helped to describe the characteristics of the variables of this study and to find out the underlying features of the relationships between BPR strategies, information technology Infrastructure and service delivery on firm performance of food manufacturing companies in Kenya. [27] contend that descriptive statistics provide the basic features of the data collected. To compute the firm performance index, weighted scores (adopted from GoK, 2018) with an average of five years will be computed as follows:

Step 1: Determine the Actual Achievement for each firm performance indicators, $\mathrm{X}_{\text {year } 1-5}$

Step 2: Find the average Score of the five-year Actual Achievement for each firm performance indicators, Average Score $=\left(\mathrm{X}_{\text {year } 1+} \mathrm{X}_{\text {year } 2+} \mathrm{X}_{\text {year } 3+} \mathrm{X}_{\text {year } 4+} \mathrm{X}_{\text {year } 5}\right) / 5$

Step 3: Compute the Weighted Score by Multiplying the Average Score by the weight assigned to the indicator as a percentage to obtain the Weighted Score, i.e. Weighted Score $=$ Average Score $\mathrm{x}$ Indicator Weight as a percentage

Step 4: Compute the Composite Score of each food manufacturing company by adding up the weighted scores of all the performance indicators to obtain the firm performance index.

After the computation of firm performance index, inferential statistics technique included Person's product moment coefficient correlation ( $\mathrm{r}$ ), hierarchical regression analysis, stepwise multiple regression analysis and multiple linear regression analysis. All the statistical tests was conducted at 95 percent level of confidence. The researcher used multiple regression analysis as in table 3 on summary of objectives, hypotheses and analytical model. 
TABLE 3: SUMmARY OF OBJECTIVES, HyPOTHESES AND ANALYTICAL MODEL

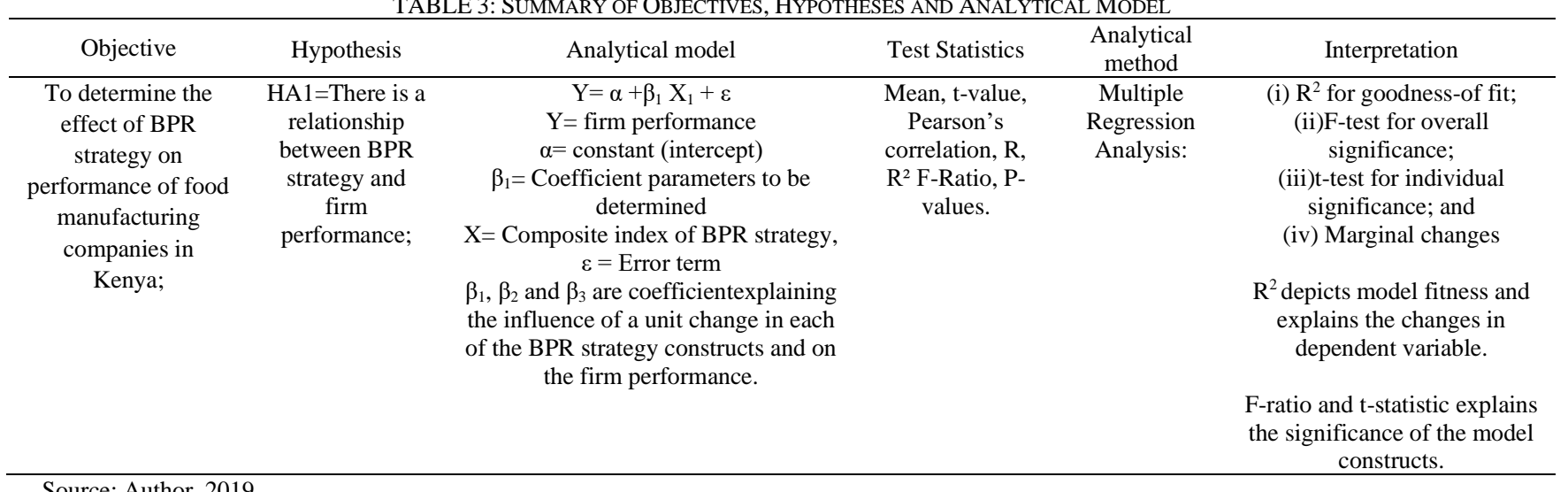

\section{DATA ANALYSIS AND FINDINGS}

The classical linear regression model is based on a number of assumptions including linear relationship, multivariate normality, no or little multicollinearity, no auto-correlation and homoscedasticity. A multiple linear regression analysis was performed to test the assumptions on the variables in the study. The Stepwise method was used to enter the variables in the equation. Linear regression analysis requires that there is little or no autocorrelation in the data. Autocorrelation occurs when the residuals are not independent from each other.

The study was a descriptive cross-sectional survey of 75 food-manufacturing firms operating in Kenya. Each food manufacturing organization is believed to exhibit uniqueness in relation to the business process re-engineering practices, information technology infrastructure, service delivery and firm performance. The questionnaires were self-administered with the help of well-trained research assistants. This represented a response rate of $56.67 \%$.

The study sought to determine the effect of BPR strategy on performance of food manufacturing companies in Kenya. The hypothesis was:

$\mathrm{H}_{\mathrm{A} 1}$ : There is a significant relationship between BPR strategy and performance of food manufacturing companies in Kenya.

The study tested the direct effects of BPR strategy dimensions on the firm performance. This was through performing a regression analysis to determine and test the hypothesis for the existence of a link between BPR strategy on firm performance.

Overall composite firm performance index on firm performance was composite index was derived from the six perspectives that were used to measure of firm performance: finance and stewardship, operational/efficiency, quality, logistics/supply chain, people/human resource, and compliance/regulatory. Then the results from testing the first hypothesis on whether there is any existence of a link between BPR strategy and firm performance was done through multiple regression analysis giving the results as in the tables below.

From the findings on Table 4, all the seven indicators of BPR strategy were included in the multiple regression analysis testing the relationship between BPR strategy and firm performance. Further the model goodness of fit using the adjusted $\mathrm{R}^{2}$ (coefficient of determinations) done in the next table.

TABLE 4: VARIABLES ENTERED/REMOVED ON THE RELATIONSHIP BETWEEN BPR STRATEGY AND FIRM PERFORMANCE

\begin{tabular}{|c|c|c|c|}
\hline Model & Variables Entered & $\begin{array}{l}\text { Variables } \\
\text { Removed }\end{array}$ & Method \\
\hline 1 & $\begin{array}{l}\text { Resources Mobilization for BPR, Sponsorship } \\
\text { and Commitment, BPR Cross functional Teams, } \\
\text { Analytical Processes Selection, BPR Prototypes, } \\
\text { Management of Re-engineered Processes, Clear } \\
\text { BPR Definition and Visionb }\end{array}$ & Nil. & Enter \\
\hline $\begin{array}{l}\text { a. I } \\
\text { b. } \\
\text { Sol }\end{array}$ & $\begin{array}{l}\text { Dependent Variable: Firm Performance Index. } \\
\text { All requested variables entered. } \\
\text { urce: Research Data (2019) }\end{array}$ & & \\
\hline
\end{tabular}

TABLE 5: MODEL GOODNESS OF FIT OF ON THE RELATIONSHIP BETWEEN \begin{tabular}{ccccc}
\multicolumn{4}{c}{ BPR STRATEGY AND FIRM PERFORMANCE } \\
\hline Model & $\mathbf{R}$ & $\mathbf{R}^{\mathbf{2}}$ & Adjusted R & Std. Error of the Estimate \\
\hline 1 & $836^{\mathrm{a}}$ & 698 & 639 & 16.86676
\end{tabular} a. Predictors: (Constant), Resources Mobilization for BPR, Sponsorship and Commitment, BPR Cross functional Teams, Analytical Processes Selection, BPR Prototypes, Management of Re-engineered Processes, Clear BPR Definition and Vision.

Source: Research Data (2019).

As presented in Table 5, 63.9\% (Adjusted $\mathrm{R}^{2}=0.639$ ) of variations in the overall firm performance is explained by variations in the BPR strategy namely Resources Mobilization for BPR, Sponsorship and Commitment, BPR Cross functional Teams, Analytical Processes Selection, BPR Prototypes, Management of Re-engineered Processes, Clear BPR Definition and Vision.

Table 6 presents that the model is statistically significant in explaining the relationship between the BPR strategy and firm performance, $\mathrm{F}(7,36)=11.892, \mathrm{P}>0.000$.

TABLE 6: MODEL OVERALL SIGNIFICANCE OF BPR STRATEGY AND FIRM PERFORMANCE

\begin{tabular}{ccccccc}
\hline \multicolumn{7}{c}{ PERFORMANCE } \\
\hline \multicolumn{1}{c}{ Model } & Sum of Squares & df & Mean Square & F & Sig./P-Value \\
\hline \multirow{2}{*}{1} & Regression & 23682.048 & 7 & 3383.150 & 11.892 & $.000 \mathrm{~b}$ \\
& Residual & 10241.558 & 36 & 284.488 & & \\
& Total & 33923.605 & 43 & & & \\
\hline
\end{tabular}

a. Dependent Variable: Firm Performance Index

b. Predictors: (Constant), Resources Mobilization for BPR, Sponsorship and Commitment, BPR Cross functional Teams, Analytical Processes Selection, BPR Prototypes, Management of Re-engineered Processes, Clear BPR Definition and Vision

Source: Research Data (2019)

As presented in Table 7, using standardized coefficients: BPR prototypes a strong positive effect on firm performance 
$(\beta=0.586, \mathrm{t}=2.589, \mathrm{P}>0.014) ;$ analytical $\mathrm{BPR}$ processes selection has a weak positive effect on firm performance $(\beta=$ $0.084, \mathrm{t}=0.207, \mathrm{P}>0.837$ ); clear BPR definition and vision has a weak positive effect on firm performance $(\beta=0.320$, $\mathrm{t}=0.792, \mathrm{P}>0.433)$; resources mobilization for $\mathrm{BPR}$ has $\mathrm{a}$ strong negative effect on firm performance $(\beta=-1.017, \mathrm{t}=$ 5.261, P>0.000); the BPR cross functional teams has a weak negative effect on firm performance $(\beta=-0.406, \mathrm{t}=-1.966$, $\mathrm{P}>0.057)$; BPR sponsorship and commitment has a weak negative effect on firm performance $(\beta=-0.108, \mathrm{t}=-0.773$, $\mathrm{P}>0.444)$; and lastly management of re-engineered processes has a weak negative effect on firm performance $(\beta=-0.127$, $\mathrm{t}=-0.551, \mathrm{P}>0.585)$ The relationships derived are statistically significant.

TABLE 7: REGRESSION COEFFICIENTS OF BPR STRATEGY AND FIRM PERFORMANCE MODEL COEFFICIENTS ${ }^{\text {a }}$

\begin{tabular}{|c|c|c|c|c|c|c|}
\hline & \multirow[t]{2}{*}{ Model } & \multicolumn{2}{|c|}{$\begin{array}{c}\text { Unstandardized } \\
\text { Coefficients }\end{array}$} & \multirow{2}{*}{$\begin{array}{c}\text { Standardized } \\
\text { Coefficients }\end{array}$} & \multirow[t]{2}{*}{$\mathrm{t}$} & \multirow{2}{*}{$\begin{array}{l}\text { Sig./P- } \\
\text { Value }\end{array}$} \\
\hline & & B & Std. Error & & & \\
\hline & (Constant) & 89.977 & 36.597 & & 2.459 & .019 \\
\hline & BPR Prototypes & 15.958 & 6.163 & .586 & 2.589 & .014 \\
\hline & $\begin{array}{l}\text { Clear BPR } \\
\text { Definition and } \\
\text { Vision }\end{array}$ & 19.341 & 24.413 & .320 & .792 & .433 \\
\hline & $\begin{array}{l}\text { Analytical } \\
\text { Processes Selection }\end{array}$ & 5.339 & 25.782 & .084 & .207 & .837 \\
\hline 1 & $\begin{array}{l}\text { Sponsorship and } \\
\text { Commitment }\end{array}$ & -4.322 & 5.589 & -.108 & -.773 & .444 \\
\hline & $\begin{array}{l}\text { Management of Re- } \\
\text { engineered } \\
\text { Processes }\end{array}$ & -8.226 & 14.919 & -.127 & -.551 & .585 \\
\hline & $\begin{array}{l}\text { BPR Cross } \\
\text { functional Teams }\end{array}$ & -17.480 & 8.891 & -.406 & -1.966 & .057 \\
\hline & $\begin{array}{l}\text { Resources } \\
\text { Mobilization for } \\
\text { BPR }\end{array}$ & -26.146 & 4.970 & -1.017 & -5.261 & .000 \\
\hline
\end{tabular}

The regression equation derived was thus as follows:

$$
\begin{gathered}
Y_{l}=0.586 B P R P+0.320 B P R D V+0.084 B P R A P S- \\
1.017 R M F B P R-0.406 \text { BPRCFT }-0.127 \text { MREP }-0.108 \\
\text { BPRSC }
\end{gathered}
$$

Where:

$\mathrm{Y}_{1}=$ Firm performance

BPRP $=$ BPR Prototypes

BPRDV $=$ Clear BPR Definition and Vision

BPRAPS $=$ Analytical Processes Selection

RMFBPR $=$ Resources Mobilization for BPR

BPRCFT $=$ BPR Cross functional Teams

MREP = Management of Re-engineered Processes

BPRSC $=$ Sponsorship and Commitment

The regression model suggests that a unit operationalization of BPR Prototypes increases firm performance by 0.586 units, a unit clear BPR definition and vision increases firm performance by 0.320 units, a unit analytical processes selection increases firm performance by 0.084 units, a unit lack of sponsorship and commitment decreases firm performance by 0.108 units, a unit mismanagement of re-engineered processes decreases firm performance by 0.127 units, a unit failure to use BPR cross functional teams decreases firm performance by 0.406 units, and a unit failure to engage in resources mobilization for BPR decreases firm performance by 1.017 units.

The findings therefore confirm alternate hypothesis one (1) that there is a significant relationship between BPR strategy and performance of food manufacturing companies in Kenya. $\mathrm{H}_{\mathrm{A} 1}$ is therefore supported.

\section{DISCUSSION OF FINDINGS}

The first objective of the study aimed at determining the effect of BPR strategy on performance of food manufacturing companies in Kenya. This objective had a corresponding hypothesis, $\mathrm{H}_{\mathrm{A} 1}$, which stated that there is a significant relationship between BPR strategy and performance of food manufacturing companies in Kenya.

In testing the first hypothesis on the relationship between BPR strategy and performance of food manufacturing companies in Kenya, the results showed that there is a significant relationship between BPR strategy and performance of food manufacturing companies in Kenya $\left(\mathrm{R}^{2}\right.$ $=63.9 \%$ ).

These findings fit well into the existing body of knowledge by holding that BPR strategy influence the firm's level of performance and vice versa. As contended by [6] that a congruent performance measurement system is a prerequisite for the successful design and implementation of BPR thus firm performance has to balance a number of dimensions and to play a number of roles to enable BPR to succeed thus

These results are in consistent earlier conceptual and empirical evidence by [11] argument that that performance can be improved through business process improvements that maximizes their customer satisfaction for better profitability, increased sales volume, which ultimately improves overall performance benefit.

The finding has further provided new insights on how to measure firm performance based on overall firm objectives contextually within food manufacturing companies. The new insight extended [29] use of at least three firm performance perspectives based on the generic firm objectives of profitability, market share and cost reduction. [23] narrow use of two performance perspectives of human resource productivity and quality improvement were explored for the new insights. The current study introduced five more firm performance objectives that contextually addressed the performance objectives of a food manufacturing company specially issues to do with: operational/efficiency, quality, logistics/supply chain, people/human resource and compliance/regulatory requirement on food hygiene.

Conceptually, the empirical relationship between BPR strategy and firm performance is significant where BPR strategy constructs independently and positively plays a role of fostering firm performance whereby the three significant predictors were: BPR prototypes, clear BPR definition \& vision, and analytical processes selection. These three are distinct development elements of the BPR strategy which competitors are unable to imitate in the food manufacturing. Hence the study confirms and supports [30] Resource Advantage (R-A) theory which guides the improvements meant to enhance organizational performance. 


\section{SUMMARY OF FINDINGS}

On hypotheses testing, it was established that: Firstly, $63.9 \%$ of variations in the overall firm performance is explained by variations in the BPR strategy namely resources mobilization for BPR, sponsorship and commitment, BPR cross functional teams, analytical processes selection, BPR prototypes, management of re-engineered processes, clear BPR definition and vision. Thus, there is a significant relationship between BPR strategy and performance of food manufacturing companies in Kenya. $\mathrm{H}_{\mathrm{A} 1}$ is therefore supported.

\section{CONCLUSION}

The study concludes that firstly, there is a positive and statistically significant relationship between BPR strategy and performance of food manufacturing companies in Kenya whereby $63.9 \%$ of variations in the overall firm performance are attributed to the changes in the BPR strategy namely resources mobilization for BPR, sponsorship and commitment, BPR cross functional teams, analytical processes selection, BPR prototypes, management of reengineered processes, clear BPR definition and vision. The results therefore support the anchoring theory of resource advantage theory.

\section{RECOMMENDATIONS}

The research findings have addressed the key gaps in this study. On the scantly investigated the effect of BPR strategy on firm performance empirically, findings fit well into the existing body of knowledge by holding that BPR strategy influence the firm's level of performance and vice versa. As contended by (Kuwaiti \& John, 2000) that a congruent performance measurement system is a prerequisite for the successful design and implementation of BPR thus firm performance has to balance a number of dimensions and to play a number of roles to enable BPR to succeed.

\section{LIMITATIONS OF STUDY}

A cross sectional survey approach method was used for the study and data was collected was collected at only one point in time which may bias the findings and given that, the study was done within food manufacturing companies in Kenya, which has certain peculiarities. A single respondent was used in data collection, which may bias or determine the nature of responses.

\section{SUGGeStiOnS FOR FURTHER RESEARCH}

Overall firm performance was measured by finance and stewardship, operational/efficiency, quality, logistics/supply chain, people/human resource, and compliance/regulatory. The study used logistics/supply chain performance as one of the perspectives of firm performance. This did not treat supply chain performance outcome as a mediating variable. Future research can test the mediating effect of supply chain performance in the relationship between BPR strategy and firm performance. This will involve checking whether the SC performance has an influence on firm performance.

\section{REFERENCES}

[1] Smart, P. A., Maddern, A. \& Maull, R. S. 2009. Understanding Business Process Management: Implications for Theory and Practice. British Journal of Management, 20: 491-507.

[2] Johnson, G., Scholes, K. and Whittington, R. (2008) Exploring Corporate Strategy. Pearson Education Limited, Essex.

[3] Kohibacher, F. 2008. Knowledge-based new product development: Fostering innovation through knowledge co-creation, International Journal of Technology Intelligence and Planning. 4(3): 326-346.

[4] Bhatt, G. D., \& Trout, M. D. (2005). Examining the relationship between business process initiatives, information systems, integration and customer focus: an empirical study. Business Process Management Journal, 11(5), 532-558.

[5] Smith, A., Meade, M., Wolf, D. \& Song, J. 2013. The CSF's, quality governance, BPR performance and gaining competitive advantage International Journal of Business and Management, 8(24): 48 - 63.

[6] Kuwaiti M.E \& John M. K, (2000),"The role of performance measurement in business process reengineering", International Journal of Operations \& Production Management, Vol. 20 Iss 12 pp. 1411 1426.

[7] Hammer, M. and Champy, J. (1993), Reengineering the Corporation: a Manifesto for Business Revolution, McGraw-Hill, New York, NY.

[8] Ringim, K. J., Razalli, M. R., \& Hasnan, N. (2011). Effect of Business Process Reengineering Factors on Organizational Performance of Nigerian banks: Information Technology Capability as the Moderating Factor. International Journal of Business and Social Science, 2(13).

[9] Goll, E.O. \& Cordovano, M.F. "Construction Time Again," CIO, October 15, 1993, pp. 32-36.

[10] Wong, W.P., Ahmad, N.H., Nasurdin, A. M. \& Mohammad, M.N. 2013. The Impact of External Environmental on Business Process Management and Organizational Performance. Serv Bus, 17 September: 559-586. Stellenbosch University https://scholar.sun.ac.za

[11] Razalli, M.R. (2008). The consequence of service operations practice and service responsiveness on Hotel performance: Examination of Hotels in Malaysia. Unpublished PhD Thesis, University Sains Malaysia, (USM)

[12] Rinaldi, M., Montari, R. \& Botani, E. 2015. Improving the efficiency of public administrations through business process re-engineering and simulation: a case study. Business Process Management, 21(2): 419462 .

[13] World Bank, 2017)., Improving Nutrition through Multispectral Approaches (Washington, DC: World Bank. 2017. Doing Business. [Online].

[14] Al-Mashari, et al. (2001), "Process reengineering: a survey of international experience", Business Process Management Journal, Vol. 7 No. 5, pp. 437-53, in E. Loukis K. Pazalos St. Georgiou, (2009), "An empirical investigation of the moderating effects of BPR and TQM on ICT business value", Journal of Enterprise Information Management, Vol. 22 Iss 5 pp. $564-586$.

[15] Chris Richards, (2018). Business Productivity Review - EEF submission: CPR and CE Marking, Department for Business, Energy and Industrial Strategy.

[16] Barney, J.B. (1991), a Firm resources and sustained competitive advantage.

[17] Fahy, J. (2000). The resource-based view of the firm: some stumblingblocks on the road to understanding sustainable competitive advantage. Journal of European Industrial Training, 24/2/3/4.

[18] Gottschalg, O. and Zollo, M. (2007). Interest alignment and competitive advantage. Academy of Management Review, Vol. 32, No. 2, pp. 418-437.

[19] MacLean L. M, Meyer M. and Estable A., (2004): Improving Accuracy of Transcripts in Qualitative Research. Qualitative Health Research. 2004;14(1):113-123.

[20] Slater, S.F. \& Narver, J.C. (1995). "Market Orientation and the Learning Organization”, Journal of Marketing, 59 (3): 63-74.

[21] Quinn, R. and Rohrbaugh, J. (1983) A Spatial Model of Effectiveness Criteria: Toward a Competing Values Approach to Organizational Analysis. Management Science, 29, 363-377.

[22] Venkatraman, N. (1994). I.T-enabled business transformation: from automation to business scope redefinition. Sloan Management Review, 35(2), 73-87.

[23] Santos-Vijande, L., Sanzo-Pérez, M.J., Gutiérrez, J.A.T. and Rodríguez, N.G. (2012) 'Marketing capabilities development in small 
and medium enterprises: implications for performance',Journalof Centrum Cathedra, Vol. 5, No. 1, pp.24-42.

[24] Cooper, R. and Kaplan, R.S. (1988), “How cost accounting distorts product costs", Management Accounting, April, pp. 20-7. In Kuwait M.E \& John M. K, (2000),"The role of performance measurement in business process reengineering", International Journal of Operations \& Production Management, Vol. 20 Iss 12 pp. 1411 - 1426.

[25] Sekaran, U. \& Bougie, R. 2013. Research Methods for Business: A Skill Building Approach. 6th edition. West Sussex: John Wiley \& Sons.

[26] Saunders, M., Lewis, P. And Thornhill, A. (2007) Research Methods for Business Students.

[27] Mugenda, O. M., \& Mugenda, A. G. (2003). Research Methods: Quantitative and Qualitative Approaches. Nairobi: African Centre for Technology Studies.

[28] Cronbach, L. J., \& Meehl, P. E. (1955). Construct validity in psychological tests. Psychological Bulletin, 52, 281-302. doi: 10.1037/h0040957.

[29] Kirby, P. (2005), 'The Irish State and the Celtic Tiger: A "Flexible Developmental State" or a CompetitionState?', in Graham Harrison (ed.),Global Encounters: International Political Economy, Developmentand Globalisation(Basingstoke: Palgrave: Macmillan), pp. 74-94.

[30] Ferdinand, A.T., Widiyanto, I. and Sugiarto, Y., 2012. Readings In Theory Of Marketing And Entrepreneurship. Semarang: Universitas Diponegoro.

\section{Richard Nyaanga Ongeri}

Ph.D. Candidate, Department of Management Science, School of Business - University of Nairobi, Nairobi - Kenya.

Peterson Obara Magutu, PhD.

Senior Lecturer, Department of Management Science, School of Business - University of Nairobi, Nairobi - Kenya.

Kate Litondo

Associate professor, Department of Management Science, School of Business - University of Nairobi, Nairobi - Kenya. 